\title{
EDITORIAL
}

\section{The Costs of Scholarly Teaching and Learning}

\author{
Amy M. Goodburn, PhD \\ Associate Dean for Faculty, College of Arts and Sciences \\ Professor, Departments of English and Women and Gender Studies \\ Co-coordinator, Peer Review of Teaching Project \\ University of Nebraska-Lincoln
}

At the University of Nebraska-Lincoln (UNL) I come to SoTL work from several different locations: As an English professor in composition and rhetoric; as an associate dean for faculty within the College of Arts and Sciences; and as cocoordinator of a faculty teaching development program. This past spring was especially challenging as the country's economic free-fall led to a year filled of budget-planning exercises, which then turned into budget-cut proposals, and now impending--but still not determined--budget cuts. In many ways, UNL has fared better than most other universities nationwide. The state of Nebraska received national attention when it was named the financially "happiest state" in the country by MainStreet.com based on factors of economic well-being. UNL did not face the mid-year budget cuts that forced other institutions to freeze hiring, fire and furlough staff and faculty, and/or increase teaching loads. While the threat of budget cuts was a cloud that hovered over us throughout the year, the actual financial impact for this year was negligible. Indeed, because we were one of the few institutions continuing to hire, we benefited from a buyer's market, hiring a wonderful group of new faculty who might not otherwise have given UNL a second look. Wearing the hat of associate dean for faculty, I can say it was definitely a good year.

The numerous budget and strategic planning meetings in which I participated did give me pause, however, in thinking about the institutional structures that support the scholarship of teaching and learning (SoTL). As I began to see how budget decisions were being made, I began to view UNL's institutional structures that support SoTL as highly vulnerable, spurring me to think more critically

\author{
What I had not fully \\ considered is how my \\ institution's structures lack \\ mechanisms for making \\ visible SoTL's centrality to \\ the academic mission in \\ economic terms.
} about the about the costs entailed in SoTL work and the ways that SoTL advocates might better argue for its value in economic terms.

It is not that I haven't considered the costs of engaging in SoTL work before. But previously I viewed the issue of cost primarily in relation to the faculty members who sought to engage in such work. In other words, I understood the issue in terms of how to support and reward faculty who seek to do SoTL, and how, equally, to combat other faculty members' perceptions that time spent on SoTL is "wasted" time not spent on generating grant dollars and scholarly publications.

What I had not fully considered is how my institution's structures lack mechanisms for making visible SoTL's centrality to the academic mission in economic terms. For instance, as I prioritized the budget planning proposals from the 29 departments, programs, and centers in my College, here are some of the primary metrics I was asked to consider:

- the number of student credit hours generated,

- the amount of research grant dollars funded,

- the ratio of student credit hour production per faculty FTE, and

- the number of undergraduate majors per program.

While these metrics were useful in comparing and evaluating programs across different departments, they led me to wonder how the faculty development project that I co-coordinate and which is funded out of the Senior Vice Chancellor's Office could compete. How could these metrics be used to assess a SoTL program 
that is focused on helping faculty improve teaching across an institution? How can a program that does not directly produce student credit hours, that does not visibly generate grant dollars, that does not directly increase the number of student majors, claim centrality to the institution's academic mission?

A February meeting with the Senior Vice Chancellor's team posed similar questions about this program, which supports faculty throughout a year to document and make visible teaching and learning in a target course. While the SVCAA's Office has been highly supportive of this program (funding it to the tune of about $\$ 80,000$ per year), this year the team requested more quantitative data that the project is having a direct impact on student learning. While we have collected survey data from previous faculty participants demonstrating that over $94 \%$ feel that the project has helped them to 1 ) better define course goals, 2) identify and articulate learning objectives, 3) revise course design, and 4) better articulate their expectations for students' learning, we still haven't figured out a way to collect data that shows a direct impact on students' learning. We haven't developed a way to speak directly to the metrics that the university is using to assess economic impact in relation to academic mission.

From its inception SoTL work has relied on collecting data and evidence to make arguments about what constitutes best practices in teaching and learning. Such work has been framed as systematic and ongoing, cycling back into practice for continuous improvement of teaching and learning, and making such work public and available for use by others, both institutionally and disciplinarily. But I suggest that in the present academic climate, SoTL advocates need to be more concrete about how to frame SoTL's benefits in economic terms.

Lee Shulman (2000), former president of the Carnegie Foundation, has similarly argued for the need to engage in policy discussions about SoTL's economic value:

Those who make policies and approve budgets for our institutions are increasingly asking for evidence that we are making measurable progress toward our educational goals... I envisage a scholarship of teaching and learning offering the kinds of evidence that can be powerful in these policy and free market discussions. (p. 52)

So how can those of us who care about SoTL work help educate university decisionmakers about its economic value?

One example was illustrated in the March 13 2009 edition of The Chronicle of Higher Education. In an editorial titled "On the Bottom Line, Good Teaching Tops Good Research," Frank Heppner, an honors professor of biological sciences at the University of Rhode Island, compares the money that faculty at his institution generate with grants to money that faculty with strong teaching practices generate in tuition when they retain students. Heppner (2009) argues that by retaining five

But I suggest that in the present academic climate, SoTL advocates need to be more concrete about how to frame SoTL's benefits in economic terms. students who normally would drop out each semester, his teaching recovers about $\$ 250,000$ in lost tuition, a sum comparable to the average grant earners at his school.

Heppner's overall argument is that institutions benefit economically by supporting faculty teaching development (2009). What I also find valuable about Heppner's argument, however, is that the approach he took to retain his students was systematic, documented, and based on collection of data--the same principles that undergird scholarly approaches to teaching and learning. Although he does not use the language of SoTL within his editorial, the headline easily could have been titled "Scholarly Teaching is Cost-Effective" or "SoTL Approaches Retain Students and Save Money." Heppner's argument raises questions that I think SoTL advocates need to consider more fully. How can we ground our claims for SoTL's importance 
within terms that policy makers and university administrators can understand and act upon? What are the economic benefits to institutions that value and reward SoTL? And what are the costs to institutions that do not? As a teacher, administrator, and faculty developer, these are the SoTL questions that I am continuing to wrestle with as I prepare for the next academic year.

\section{References}

Heppner, F. (2009, March 13). On the bottom line: Good teaching tops good research. The Chronicle of Higher Education, pp. A72.
Shulman, L. (2000). From minsk to pinsk: Why a scholarship of teaching and learning? Journal of Scholarship of Teaching and Learning, 1, 48-53.

Amy Goodburn is Professor of English and Associate Dean for Faculty in the College of Arts and Sciences at the University of Nebraska-Lincoln. Her research and teaching interests include critical and multicultural pedagogies, ethnographic and teacher research, and documenting and assessing teaching and learning in postsecondary education. Her recent books include Inquiry into the College Classroom: A J ourney Toward Scholarly Teaching (with Paul Savory and Amy Burnett) and Making Teaching and Learning Visible: Peer Review and Course Portfolios (with Dan Bernstein, Paul Savory, and Amy Burnett). Since 2001 she has co-coordinated UNL's Peer Review of Teaching Project, a year-long program that supports faculty in documenting and assessing student learning. In 2002, Dr. Goodburn was inducted into UNL's Academy of Distinguished Teachers. 